\title{
Effects of Land-Use Change on Under Storey Species Composition and Distribution in Tropical Rainforest
}

\author{
Anthony Ifechukwude ODIWE I*, Joshua Oluwole OLOWOYO², Olufemi AJIBOYE ${ }^{1}$ \\ ${ }^{1}$ Obafemi Awolowo University, Department of Botany, O.A.U. P. O. Box. 1992, Ile- \\ Ife, Osun State, Nigeria; aiodiwe@oauife.edu.ng (*orresponding author) \\ ${ }^{2}$ University of Limpopo, Department of Biology, P. O. Box 139, Medunsa Campus, Garankuwa, Pretoria, 0204, South Africa
}

\begin{abstract}
The forest land's conversion into tree crops plantations plays a major role in the loss of biodiversity. Therefore, understanding the impacts of land-use change on species diversity is very critical for ecosystem functioning and stability. This study was carried out to evaluate the effect of land-use changes on under storey species diversity in the Theobroma cacao and Citrus sinensis plantations. Two, 25 $\mathrm{m} \times 25 \mathrm{~m}$ plots were sampled in each plantation and a nearby undisturbed secondary rainforest for comparison. The diameters (dbh-1.3 $\mathrm{m}$ ) of all trees at breast height $>10 \mathrm{~cm}$ were measured in each plot. Five line transect were systematically laid and a quadrat of $50 \mathrm{~cm} \times 50$ $\mathrm{cm}$ placed at every $1 \mathrm{~m}$ point to identify the under storey species (herbaceous, shrubs, tree saplings and climbers) present in each plot. Percentage canopy, species diversity using Shannon-Wiener, Simpson's index and Evenness were determined, while species similarity was determined using the Jaccard's similarity index. Results indicate that woody basal area and stem density in Theobroma cacao were significantly $(\mathrm{P}<0.05)$ higher than the Citrus sinensis plantation. A total number of 25, 27, and 14 under storey species distributed in 16, 19 and 11 families were found in Theobroma cacao, Citrus sinensis plantations and secondary forest respectively. Panicum maximum and Axonopus compressus were the dominant grasses in the Theobroma cacao and Citrus sinensis plantations respectively. The percentage canopy cover was significantly $(\mathrm{P}<0.05)$ higher in the secondary forest than the plantations. The land use modification has significantly increased the under storey species composition.
\end{abstract}

Keywords: land-use change, under storey species, biodiversity, plantations, species diversity

\section{Introduction}

The lowland rainforest has been reported to be the most species-rich terrestrial ecosystem having more than $50-70 \%$ of all living organisms on approximately $6-7 \%$ of the land area (Linsenmair, 1990, 1997; Wilson, 1992). The forests, being continuously cut down in order to build facilities for industrial complexes or to provide products for industrial development (Sanderson et al., 2004) and this has continued at a very alarming rate (Pimm et al., 1995; Prance et al., 2000). The continuous degradation of the forest reserve base has been reported to lead to the rapid disappearance of forest cover leading to erosion, loss of biological diversity, soil degradation, and unfavorable hydrological changes (Aweto 2000, 2001; Aweto and Ekuigbo, 1994). It has been pointed out that about $8 \%$ of the scientifically known plant species on earth are presently on the verge of being wiped out (Chapin et al., 2000).

The impacts that have been of primary concern are the effects of land-use change on biological diversity, soil degradation and the ability of biological systems to support human needs. Tree crop species plantation has become mostly planted in most countries due to the fact that it is fast-growing and because of the economic value (Lavery and Mead, 1998). Over the years, plantations of fast-growing exotic tree species have become increasingly important land use in the tropical regions with following tree crops species; Theobroma cacao, Cola nitida, Coffea arabica, Citrus sinensis, Elaeis guinensis, and fast-growing timber trees like Gmelina arborea, Tectona grandis plantations becoming more common in Nigeria because of their economic gain, and also the need to control soil erosion and soil degradation. The availability of plantation forestry has also been pointed out to reduce pressure on native forests (Ponce, 2000), which are rapidly being depleted (IINEFAN, 1995).

Land-use change has been reported to have one of the largest global impacts on biodiversity (Chapin et al., 2000; Sala et al., 2000). The type and intensity of land use change will influence the number of species occurring in different habitats. Plant species diversity has been widely studied in the plantation ecosystems (Kamo et al., 2002; Nagaike, 2002; Nagaike et al., 2003; Pourbabaei and Roostami, 2007; Yirdaw, 2001, 2003). The under storey plants have been reported to be a major component of forest ecosystems and play an important role in many ecological functions and processes (Nagaike et al., 2006; Roberts, 2002; Yirdaw, 2001). Studies of plant species diversity in the for- 
est under storey and in plantations abounds, where high species diversity of under-story plants has been reported within plantations in surrounding natural forests (Nagaike, 2002; Nagaike et al., 2006; Yirdaw, 2001).

Biodiversity is changing at an unprecedented rate as a complex response to several human-induced changes ( $\mathrm{Vi}$ tousek et al., 1994). A high biodiversity is seen as an insurance against a decline in ecosystem service and should therefore be preserved (Yachi and Loreau, 1999). The under storey composition is changing in space and time due to a multitude of factors such as grazing, fire and rainfall, which differs in intensity and duration. It is therefore very necessary to conserve the under storey vegetation in the forest and plantations ecosystems. Although this land-use change has grown over the past years and the impact on the species diversity has been extensively studied in different parts of the world, however, little is known about the effect of the change in vegetation from forest to plantations on under storey species in Nigeria. Most research in the plantations' ecosystems focused on the impact of conversion of forest vegetation to plantation on soil properties (Adejuwon and Ekanade, 1988; Ekanade, 1985, 1988; Wessel, 1969). Muoghalu and Odiwe (2011) have also worked on litter production and decomposition in some of these plantations. Therefore, there is the need to evaluate and document the impact of the land use changes on under storey species diversity in order to increase the understanding of species' distribution, especially with the concerns for loss of biodiversity associated with the conversion of the rainforest to tree crops plantations.

This study specifically examined the under storey plant species in Theobroma cacao, Citrus sinensis plantations and, compares the species diversity with that of a nearby rainforest with a view to provide information that will be vital to biodiversity functioning and conservation, following the conversion of forest to plantation ecosystems, and also serves as a baseline data for future study. The following key questions were examined in this study; (i) How much of the under storey species is maintained in Theobroma cacao and Citrus sinensis, and the nearby secondary forest? (ii) What is the impact of the different land-use on the under storey species composition and distributions?

\section{Materials and methods}

\section{Study area}

The study was conducted at the Teaching and Research ( $T$ and $R$ ) farm of the Obafemi Awolowo University (OAU) Ile-Ife, Nigeria. Ile-Ife is situated within the rainforest zone, and the study sites are located on latitude $7^{\circ} 32^{\prime} \mathrm{N}$ and longitude $4^{\circ} 32^{\prime} \mathrm{E}$ within Ile-Ife, the elevation of the area ranges from 276 to $286 \mathrm{~m}$ above sea level. There are two prominent seasons in Ife area, the rainy and the dry season. The dry season is short, usually lasting 4 months from November to March, and the longer rainy season prevails during the remaining months with slight irregularity in the rainfall distribution pattern. The weather information was obtained from the Meteorological stations located within the $\mathrm{T}$ and $\mathrm{R}$ farm of OAU. The annual rainfall at Ile-Ife averaged $1413 \mathrm{~mm} \mathrm{yr}^{-}{ }^{1}$ in a 5 -year survey (Duncan, 1974) and it showed two peaks, one in July and the other in September. The mean annual temperature ranges from 22.5 to $31.4^{\circ} \mathrm{C}$. Most soils under the plantations of these tree crops have been classified as Alfisol and Ultisol (Soil Survey Staff, 1990). They are formed from old parent materials which have been subjected to intensive weathering and leaching with predominant kaolinitic clay having low cation exchange capacity and less exchange sites, hence they are considered deficient in most plant nutrients (Wassel, 1969). The original vegetation of the Ife area is lowland rainforest as climax vegetation (Keay, 1959). The forest sub-type is dry-deciduous forest (Onochie, 1979).

\section{Sampling procedure}

Two sample plots, $25 \mathrm{~m} \times 25 \mathrm{~m}$ in each plantation, (Theobroma cacao, Citrus sinensis and a nearby relatively undisturbed forest) were used for this study. The plots were laid out with a measuring tape and demarcated by narrow cut lines. The measurement was done in November (dry season month). For each site, the diameter of all the trees at breast height $(\mathrm{dbh}-1.3 \mathrm{~m}) \geq 10 \mathrm{~cm}$ were counted, numbered, identified and their density per plot determined in each plot. Five line transect were systemically laid in each plot and a quadrat of $50 \mathrm{~cm} \times 50 \mathrm{~cm}$ placed at every $1 \mathrm{~m}$ point to identify and quantify all the under storey plant species present in each plot. Those that cannot be identified at the field were taken to IFE 1 Herbarium for proper identification. Percentage canopy was also estimated. Several terms were used for describing the biodiversity traits of the plant communities: Species richness, Shannon-Wiener index of species, Simpson index and Evenness index (Pieolus, 1966).

The Diversity index $H^{\prime}$ of each sample plot was calculated using the method prescribed by Shannon and Wiener index (1963) as:

$$
\mathrm{H}=-\sum P i \ln P i
$$

Where $P i$ is the relative abundance proportion of $i$ species and $\ln =$ Natural logarithm

Evenness index (Pieolus, 1966) also calculated thus:

$$
E=\frac{H}{\ln S}
$$

where $S$ is the total species number in each plantation, $H$ is the diversity index and $\ln =$ natural logarithm.

Simpson's index of diversity (1-D) which gives the probability that two randomly selected individuals in a zone belong to different subspecies and $D$ is calculated thus:

$$
D=\frac{\sum_{i=1}^{S} n_{i}\left(n_{i}-1\right)}{N(N-1)}
$$


152

where $n$ is the number of individuals of species $i$ which are counted/encountered, and $N$ is the total number of all individuals counted/encountered.

The degree of similarity in species composition between the plantations and the nearby forest was compared using Jaccard's Index of similarity:

$$
\text { Jaccard's Index } \mathrm{C} \mathrm{j}=\frac{A}{A+B+C}
$$

where:

$A=$ number of species present in both plantations and the nearby forest

$B=$ number of species present only in the plantation and absent from the forest

$C=$ number of species present only in the nearby undisturbed forest and absent from the plantation.

\section{Statistical Analysis}

One way analysis of variance was used to test for different treatment effects (land-use types) on the basal area, stem density, species diversity and evenness in each of the plots. Means of the main effects were compared using Least significant difference $(\mathrm{LSD})$ test at $(\mathrm{P}<0.05)$. The statistical procedures were performed using SAS software, the values were first tested for normality and assumption of constant variance.

\section{Results}

A total of number of 25 and 18 under storey plant species distributed in 19 and 15 families were found in Theobroma cacao and Citrus sinensis respectively, while 14 different species were distributed in 12 families in the nearby secondary forest (Tab. 1). The basal area and stem density were significantly $(\mathrm{P}<0.05)$ higher in the nearby secondary forest compared with the plantations, where Citrus sinensis plantation had the lowest value (Tab. 1)

Basal area and stem density were significantly $(\mathrm{P}<0.05)$ higher in the nearby secondary forest compared with the plantations (Tab. 1) with the Citrus sinensis plantation having the lowest values. There was a variations in the crown cover percentage between sampling plots of studied sites and they were significantly different $(p<0.05)$. Percentage canopy cover was found to be $80.5 \%$ in the secondary forest, $71.5 \%$ in Theobroma cacao and $59.0 \%$ in Citrus sinensis plantations (Tab. 1).

The details of the species composition and frequencies in percentage are shown in Tab. 2. The most dominant

Tab. 1. Vegetation parameters measured in the different plantations and a nearby undisturbed secondary forest

\begin{tabular}{cccc}
\hline $\begin{array}{c}\text { Vegetation } \\
\text { parameters }\end{array}$ & $\begin{array}{c}\text { Theobroma } \\
\text { cacao }\end{array}$ & $\begin{array}{c}\text { Citrus } \\
\text { sinensis }\end{array}$ & $\begin{array}{c}\text { Secondary } \\
\text { forest }\end{array}$ \\
\hline Species richness & 25 & 18 & 14 \\
No of families & 19 & 15 & 12 \\
Basal area $\left(\mathrm{m}^{2} \mathrm{ha}^{-1}\right)$ & $4.18 \pm 0.57^{\mathrm{c}}$ & $12.13 \pm 0.74^{\mathrm{ab}}$ & $14.62 \pm 1.56^{\mathrm{a}}$ \\
Stem density $\left(\mathrm{ha}^{-1}\right)$ & $256^{\mathrm{c}}$ & $656^{\mathrm{b}}$ & $1152^{\mathrm{a}}$ \\
Canopy cover $(\%)$ & $59.0^{\mathrm{c}}$ & $71.5^{\mathrm{b}}$ & $80.5^{\mathrm{a}}$ \\
\hline
\end{tabular}

Values with the same letter across the row are not significantly different $(p>0.05)$ under storey species in Theobroma cacao plantation are: Commenlina benghalensis (11.5\%), Puozolzia guineensis (10.34\%) and Talinum triangulare (8.05\%). In Citrus sinensis plantations, the dominant species were: Fluggea virosa (29.06\%), Spermacoce ocymoides (19.7) and Cyperus spp (9.40\%), while Baissea subsessilis (41.7\%), Culcasia saxatilis (11.7\%), Mallotus oppositofolius (8.33) and Salacia pallescens $(9.83 \%)$ were the dominant ones in the secondary forest. The following are the rare species of the Theobroma cacao plantations; Albizia zygia (0.57\%), and Rauvolfia vomitoria (0.57\%). In Citrus sinensis-Aspillia Africana (0.85\%), Desmodium species, Ipomea involuncrata and Trichisia subscordata, while Baphia nitida (1.67\%), Combretum racemosum (1.67\%), Dracaena arborea (1.67\%) and Hiprocratea pallens (1.67\%) were the rare ones in the secondary forest, having only one individual each. Grass species are completely absent in the secondary forest while Andropogon gyanus (3.44\%) and Axonopus compressus $(8.55 \%)$ are the most dominant species in the Theobroma cacao and Citrus sinensis plantations respectively (Tab. 2).

The diversity index, Shannon Wiener, Simpson's index and evenness distribution across the plantations and the forest are presented in Fig. 1. Results showed that there were significant differences $(P<0.05)$ in mean diversity, Shannon-Wiener was highest in Theobroma cacao, and the lowest value was recorded in the secondary forest.

However, there was no significant difference $(p>0.05)$ in the Simpson index and species evenness measures among studied sites (Fig. 1), though it followed the same trend as was observed in the Shannon Wiener, where Theobroma cacao had the highest value and in Secondary forest the least. The Simpson values showed that Theobroma cacao plantation is most diverse among the study sites. From the total under storey vegetation identified, the number of common species, between the plantations, is 7, representing $20 \%$ while only two species are common between Theobroma cacao plantations and the secondary forest giving a percentage of $5.41 \%$, and one species was common to Citrus sinensis and the secondary forest giving a percentage of $3.33 \%$ (Tab. 3).

Of the total number of 48 under storey species identified and collected in this study, 23 of them are herbaceous plants, representing $48 \%$. This indicates herbaceous domi-

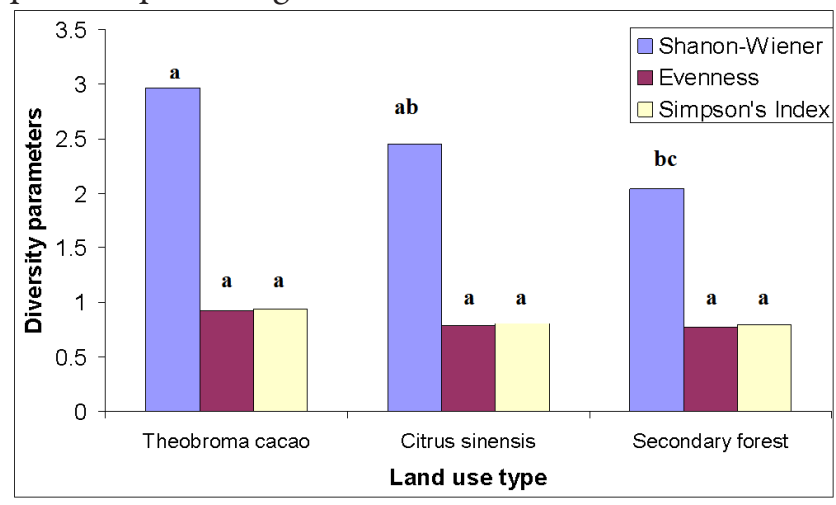

Fig. 1. Different diversity estimates of the under storey species across the land use. Values with the same letter are not significantly different $(\mathrm{p}>0.05)$ 
Tab. 2. Under storey species richness (percentage frequency in bracket) and distribution in Theobroma cacao, Citrus sinensis plantations and a nearby secondary forest sample at the study sites. The negative sign (-) stand for absence of species

\begin{tabular}{|c|c|c|c|c|}
\hline Species composition & Family & Theobroma cacao & Citrus sinensis & Secondary forest \\
\hline \multicolumn{5}{|l|}{ Herbaceous } \\
\hline Achyranthes aspera & Amaranthecaea & $4(2.99)$ & - & - \\
\hline Aspilia Africana & Asteraceae & $6(3.45)$ & $1(0.86)$ & - \\
\hline Asystacia gangetica & Acanthaceae & $7(4.02)$ & $7(5.98)$ & - \\
\hline Cissus gracilis & Vitaceae & $11(6.32)$ & - & - \\
\hline Commelina benghalensis & Commelinaceae & $20(11.49)$ & & \\
\hline Croton lobatus & Euphorbiaceae & $2(1.50)$ & - & - \\
\hline Cyathula achyranthiodes & Amaranthecaea & - & $3(2.56)$ & \\
\hline Cyperus spp & Cyperaceae & - & $11(9.4)$ & - \\
\hline Desmodium adscendes & Papilionaceae & $12(6.90)$ & - & - \\
\hline Desmodium spp & Papilionaceae & - & $1(0.86)$ & - \\
\hline Geophila obvallata & Rubiaceae & - & - & $4(6.67)$ \\
\hline Geophilla afzelii & Rubiaceae & - & - & $2(3.33)$ \\
\hline Hipprocratea pallens & Celastraceae & - & - & $1(1.67)$ \\
\hline Mallotus oppositifolius & Euphorbiaceae & - & - & $5(8.33)$ \\
\hline Puozolzia guineensis & Urticaceae & $18(10.35)$ & - & - \\
\hline Sida acuta & Euphorbiaceae & & $2(1.71)$ & - \\
\hline Spermacoce ocymoides & Malvaceae & - & $23(19.66)$ & - \\
\hline Synedrella nodiflora & Rubiaceae & - & $3(2.56)$ & - \\
\hline Talinum triangulare & Portulacaceae & $14(8.06)$ & - & - \\
\hline Trichlisia subscordata & Asteraceae & - & $1(0.86)$ & - \\
\hline Vigna gracilis & Papilionaceae & - & $3(2.56)$ & \\
\hline Vigna unguiculata & Papilionaceae & 6 & - & - \\
\hline Xanthosoma esculentum & Araceae & $6(3.45)$ & - & - \\
\hline \multicolumn{5}{|l|}{ Shrub } \\
\hline Chromolaena odorata & Asteraceae & $12(6.90)$ & $3(2.56)$ & - \\
\hline Combretum racemosum & Combretaceae & $11(6.32)$ & - & $1(1.67)$ \\
\hline Culcasia saxatilis & Araceae & - & - & $7(11.67)$ \\
\hline Dracaena arborea & Agavaceae & - & - & $1(1.67)$ \\
\hline Flueggea virosa & Euphorbiaceae & $5(2.87)$ & $34(29.06)$ & \\
\hline Lagenaria breviflora & Curcubitaceae & $3(1.72)$ & - & - \\
\hline Rauvolfia vomitoria & Apocynaceae & $1(0.58)$ & - & - \\
\hline Sphenocentrum jollyanum & Menispermaceae & & & $3(5.0)$ \\
\hline Tithonia diversifolia & Asteraceae & $4(3.0)$ & - & - \\
\hline \multicolumn{5}{|l|}{ Climber } \\
\hline Baissea subsessilis & Apocynaceae & - & - & $25(41.67)$ \\
\hline Cissampelos owariensis & Menispermaceae & $2(1.15)$ & - & - \\
\hline Ipomoea involucrata & Convolvulaceae & $2(1.50)$ & $1(0.86)$ & - \\
\hline Momordica charantia & Curcubitaceae & 9 & - & - \\
\hline Salacia pallescens & Celastraceae & $4(3.0)$ & $2(1.71)$ & $5(8.33)$ \\
\hline \multicolumn{5}{|l|}{ Tree sapling } \\
\hline Albizia zygia & Mimosaceae & $1(0.58)$ & - & - \\
\hline Baphia nitida & Papilionaceae & - & - & $1(1.67)$ \\
\hline Celtis zenkeri & Ulmaceae & - & - & $2(3.33)$ \\
\hline Acasia ataxacantha & Mimosaceae & $2(1.15)$ & - & - \\
\hline Cnestis ferruginea & Connaraceae & - & - & $2(3.33)$ \\
\hline Holarrhena floribunda & Euphorbiaceae & - & $3(2.56)$ & - \\
\hline Lecanodisus cupniodes & Sapindaceae & - & - & $1(1.67)$ \\
\hline \multicolumn{5}{|l|}{ Grass } \\
\hline Andropogon gyaanus & Poaceae & $6(3.45)$ & - & - \\
\hline Axonopus compressus & Poaceae & - & $10(8.55)$ & - \\
\hline \multicolumn{5}{|l|}{ Creeper } \\
\hline Aneilema condensata & Commelinaceae & - & $9(7.69)$ & - \\
\hline \multirow[t]{2}{*}{ Calopogonium mucunoides } & Papilionaceae & $6(3.45)$ & - & - \\
\hline & Total & 174 & 117 & 60 \\
\hline
\end{tabular}


154

Tab. 3. Jaccard's similarity index (in percent) and the number of common species shown in parenthesis for plantations and natural forest

\begin{tabular}{cccc}
\hline & $\begin{array}{c}\text { Citrus } \\
\text { sinensis }\end{array}$ & $\begin{array}{c}\text { Theobroma } \\
\text { cacao }\end{array}$ & $\begin{array}{c}\text { Secondary } \\
\text { forest }\end{array}$ \\
\hline Citrus sinensis & - & & \\
Theobroma cacao & $20(7)$ & - & \\
Secondary forest & $3.33(1)$ & $5.41(2)$ & - \\
\hline
\end{tabular}

nation in the vegetation. Shrubs comprise of 9 species giving a percentage of $19 \%$, this was followed by tree species with a total number of species, representing $15 \%$ of the total under storey species in the study area. The dominant families, encountered in this study, are presented in Fig. 3. Euphorbiaceae and Papiloniaceae are the most dominant families, each with five species followed by Rubiaceae and Asteraceae families (4 species), while the following families, Amaranthaceae, Commenlinaceae, Mennispermaceae, Mimosaceae, Celastraceae and Poaceae had two species each. The details of other growth form and the family distribution of the under storey species are shown in Fig. 2 and 3 respectively. The families with just one species are not included in Fig. 3.

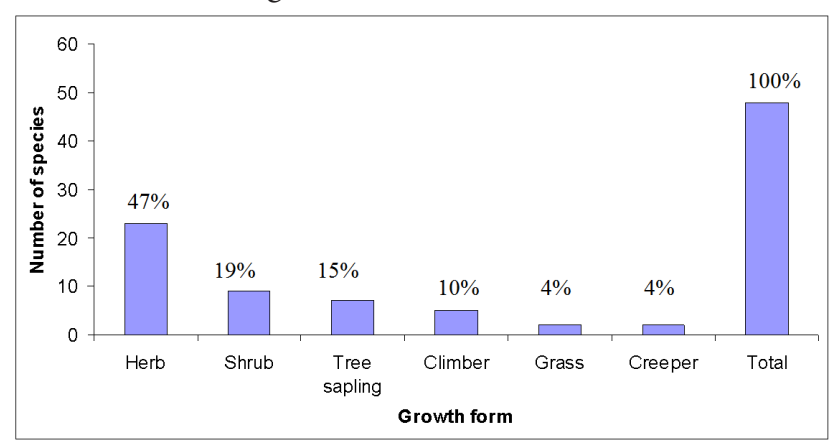

Fig. 2. Under storey Distribution by growth form of the different growth forms under storey species encountered across the study sites

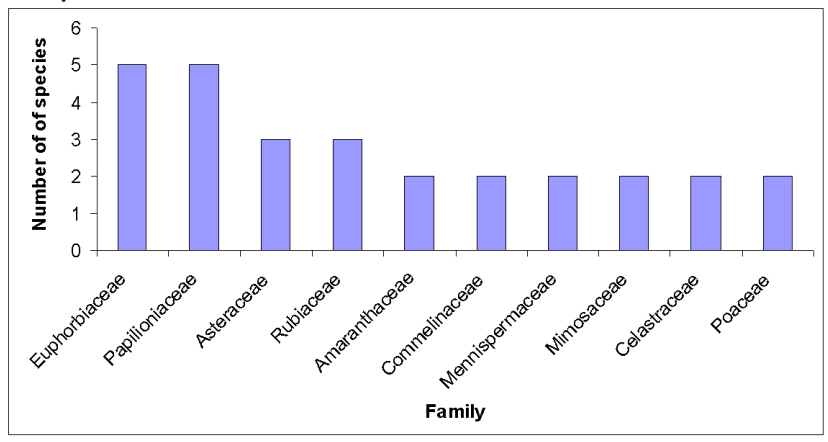

Fig. 3. Family distribution of the dominant under storey plant species encountered across the study sites

\section{Discussion}

The aim of this study was to determine the under storey plant species diversity in the plantations (Theobroma cacao and Citrus sinensis). In order to do this, a nearby secondary forest in the proximity was also sampled, since secondary forests close to the plantations site can provide baseline data that can be used in the evaluation of the impact of the land-use change on the under storey plant species diversity in plantations.

The higher number of undergrowth species (richness) recorded in the plantations in this study did not agree with the findings of Poorbabaei and Poorrrahmati (2009), where natural forest was reported to have higher species richness. The higher species' richness in the plantations, compared with the forest, might be related to the level of disturbance, in that thinning and weeding activities were carried out in the plantations. This is in agreement with the findings of Ares et al. (2010), Dodson et al. (2008), Metlen and Fiedler (2006), Thysell and Carey (2001), Wienk et al. (2004), Zenner et al. (2006), where various form of disturbance like thinning, grazing etc. have been shown to increased under storey plant cover and diversity.

The lower basal area in the plantation might be a result of the thinning cut and other management practices that were employed in the plantations while the secondary forest was not disturbed at all. This is consistent with the results of Poorbabaei and Poorrrahmati (2009), where thinning cut has also been reported to contribute to lower basal area in the Pinus taeda plantations.

The results of higher species diversity in the plantations, compared with the forest ecosystems, is in line with the findings of Koonkhunthod et al. (2007), Nagaike (2002), Nagaike et al. (2006), Poorbabaei and Poorrrahmati (2009) who have all reported higher species diversity in the plantations compared with the forest. This is however, in contrast with the results of Munoz-Reinoso (2004), Pourbabaei and Roostami (2007), Roberts (2002), Yirdaw (2001), where species diversity had been found to be lower in the plantations. The highest undergrowth plant species diversity in the plantations is expected since species richness per sampling plot was also higher in the plantations. The highest species diversity recorded at the Theobroma cacao compared with the Citrus sinensis plantation might be an indication that the plantation is more disturbed since weeding and cutting down of trees were done regularly at the site compared to Theobroma cacao plantation. Decocq et al. (2004) has reported that species diversity is higher in disturbed ecosystem than in undisturbed forest. Many other studies have pointed out that disturbances played a role in determining the species diversity (Rikhari et al., 1993; Sing et al., 2003).

The higher under storey species similarity between the plantations and the lower value between the plantations and the forest might be related to higher species richness in both plantations compared to forest. This might suggest that the secondary forest is not the main source of the seeds in plantations. The difference in relative abundance of species between the plantations and the adjacent natural forest, might have also contributed to low level of species similarity between them. Although evenness values are more or less the same across the study sites, ShannonWiener index diversity was highest in the plantations due 
to higher values of richness, this might have shown that this index is more sensitive to richness (Krebs, 1999; Ludwig and Reynolds, 1988) than evenness since the evenness are more or less the same across the study sites (Fig. 1). The sensitivity of diversity index to richness recorded in this study, however contradicts the findings of Ludwig and Reynolds (1988) and Magurran (1988).

The higher canopy cover value in the forest causes a decline in light penetration to the forest floor compared to plantations and this might have contributed greatly to lower species richness. Some studies have shown that plantation management may have severe consequences on biodiversity compared with secondary regenerated forest, since the former system usually replaced canopy tree composition with valuable timber species (Ito et al., 2004; Maestre and Cortina, 2004; Nagaike et al., 2006; Pourbabaei and Roostami, 2007; Wesenbeeck et al., 2003). The fact that forest canopies were completely replaced by Citrus sinensis and Theobroma cacao could have affected species diversity and composition. The presence of grass species in the plantations is an indication that the site is disturbed since the grasses can only thrive in an open area where more light is available.

\section{Conclusions}

It can be inferred from the present study that diversity of under storey species is closely related with the land-use change, species diversity increases in the plantations compared with the forests. High undergrowth species richness in the Theobroma cacao and Citrus sinensis plantations might possibly be used as a high potential for restoring biodiversity in the studied site; therefore, the changing in the land-use from forest to plantations has led to increase in the under storey plant species diversity. The results obtained could be used in planning of plantations (especially, in species selection) and managing of biodiversity in them and also as a baseline data for future references in this area. Although the main purpose of establishing these plantations was economical, the diversity and abundance of under storey regeneration, found in the plantation, indicated that these plantations could be effective tools in rehabilitating and increasing species diversity. There is the need to carry out further studies to assess the impact of season (rainy and dry season) on the under storey species diversity and evaluate the roles of under storey species to the nutrientcycling in both the forest and plantation ecosystems.

\section{References}

Adejuwon JO, Ekanade O (1988). Soil changes consequent upon the replacement of tropical rain forest by plantations of Gmelina arborea, Tectona grandis and Terminalia superba. J World For ResourManage 3:47-59.

Ares A, Neill AR, Puettmann KJ (2010). Understory abundance, species diversity and functional attribute response to thinning in coniferous stands. For Ecol Manage 260:11041113.
Aweto A (2000). Agriculture in Urhoboland. Paper presented at the Fifth Annual Conference of Urobo Historical Society PTI Conference. Effurum, Delta State.

Aweto A (2001). Impact of single species tree plantations on nutrient cycling in West Africa. Internat J Sustain Develop World Ecol 8:356-368.

Aweto AO, Ekuigbo UE (1994). Effect of an oil palm plantation on a tropical forest soil in South Western Nigeria. The Indon J Geography 26:51-59.

Chapin FS, Zavelata ES, Eviner VT, Naylor RL, Vitousek PM (2000). Consequences of changing biotic diversity. Nature 405:234-242.

Decocq GM, Aubert F, Dupont DR, Saguez, Wattez-Franger A (2004) Plant diversity in a managed temperate deciduos forest: under storey response to two silvicultural systems. J Appl Ecol 41:1065-1079.

Dodson EK, Peterson, DW, Harrod RJ (2008). Understory vegetation response to thinning and burning restoration treatments in dry coniferous forests of the eastern Cascades, USA. For Ecol Manage 255:3130-3140.

Duncan ER (1974). Weather from the university of Ife. Fac of Agricultural Bulletin No 2. University of Ife Press, Nigeria.

Ekanade O (1985). The effect of cocoa cultivation on some physical properties of soil in southwestern Nigeria. The Internat Tree Crops J 3:113-124.

Ekanade O (1988). The nutrient status of soil under peasant cocoa farms of varying ages in Southwestern Nigeria. Biol Agric Hortic 5:155-167.

INEFAN-Comisio'n Te'cnica para el Desarrollo Sustentable de la Industria Forestal (1995). Estrategia para el desarrollo sustentable de la industria forestal. INEFAN, Quito.

Ito S, Nakayama R, Buckley GP (2004). Effects of previous landuse on plant species diversity in semi-natural and plantation forests in a warm-temperate region in southeastern Kyushu, Japan. For Ecol Manage 196:213-225.

Kamo K, Vacharangkura T, Tiyanon S, Viriyabuncha C, Nimpila S, Doangsrisen B (2002). Plant species diversity in tropical planted forests and implication for restoration of forest ecosystems in Sakaerat, northeastern Thailand. JARQ 36(2):111-118.

Keay RWJ (1959). An outline of Nigerian Vegetation ( $3^{\text {rd }}$ edition) Government Printer, Lagos, Nigeria.

Krebs JC (1999). Ecological methodology, Harper and Row, New York, 432 p.

Koonkhunthod N, Sakurai K, Tanaka S (2007). Composition and diversity of woody regeneration in a 37-year-old teak (Tectona grandis L.) plantation in Northern Thailand. For Ecol Manage 247:246-254.

Lavery PB, Mead DJ (1998). Pinus radiata: a narrow endemic from North America takes on the world, 432-449 p. In: Richardson DM (Ed.). Ecology and Biogeography of Pinus. Cambridge University Press, Cambridge.

Linsenmair KE (1990). Tropische Biodiversität: Befunde und offene Probleme. Verh Dtsch Zool Ges 83:245-261.

LinsenmairKE(1997). Biodiversity and sustainable management 
156 of tropical forests. Nat Res Develop 45/46:13-27.

Ludwig JA, Reynolds JF (1988). Statistical ecology. John Wiley and Sons, New York, 337 p.

Maestre FT, Cortina J (2004). Are Pinus halepensis plantations useful as a restoration tool in semiarid Mediterranean areas? For Ecol Manage 198:303-317.

Magurran AE (1988). Ecological Diversity and Measurement. Princeton University Press, New Jersey.

Metlen KL, Fiedler CE (2006). Restoration treatment effects on the understory of ponderosa pine/Douglas-fir forests in western Montana, USA. For Ecol Manage 222:355-369.

Muoghalu JI, Odiwe AI (2011). Litter Production and Decomposition in Cacao (Theobroma cacao) and Kolanut (Cola nitida) plantations. Ecotropical 17:79-90.

Munoz-Reinoso JC (2004). Diversity of maritime juniper woodlands. For Ecol Manage 192:267-276.

Nagaike T (2002). Differences in plant species diversity between conifer (Larix kaempferi) plantations and broad-leaved (Quercus crispula) secondary forests in central Japan. For Ecol Manage 168:111-123.

Nagaike T, Hayashi A, Abe M, Arai N (2003). Differences in plant species diversity in Larix kaempferi plantations of different ages in central Japan. For Ecol Manage 183:177193.

Nagaike T, Hayashi A, Kubo M, Abe M, Arai N (2006). Plant species diversity in a managed forest landscape composed of Larix kaempferi plantations and abandoned coppice forests in central Japan. For Sci 52(3):324-332.

Onochie CFA (1979). The Nigerian Rainforest ecosystem: An overview, 1-13 p. In: Okali DUU (Ed.). The Nigerian Rainforest ecosystem. Proceedings of the Man and Biosphere on the Nigerian Rain Forest Ecosystem, University of Ibadan, 24-26 January, Ibadan, Nigeria.

Pieolou EC (1966). Species diversity and pattern diversity in the study of ecological succession. Theoretical Biol 10:370-383.

Pimm SL, Russell GJ, Gittleman JL, Brooks TM (1995). The future of biodiversity. Science 269:347-350.

Ponce D (2000). La forestacio'n en la Sierra ecuatoriana: el punto de vista industrial, p. 5-15. In: Medina G, Josse C, Mena PA (Eds.). La forestacio'n en los pa'ramos. Serie pa'ramo 6. GTP/Abya-Yala, Quito.

Poorbabaei H, Poorrahmati G (2009) Plant species diversity in loblolly pine (Pinus taeda L.) and sugi (Cryptomeria japonica D. Don.) plantations in the western Guilan, Iran. Internat J Biodiv Conserv 1(2):38-44.

Pourbabaei H, Roostami ST (2007). Study of plant species diversity in loblolly pine (Pinus taeda L.) plantations in the Azizkian and Lakan areas, Rasht. Environ J Tehran Univ 33(41):85-96.

Prance GT, Beentje H, Dransfiedl J, Johns R (2000). The tropical flora remains undercollected. Ann Missiri Bot Gard 87:67-71.

Rikhari HC, Negi GCS, Ram J, Singh SP (1993). Humaninduced secondary succession in alpine meadow of Central Himalaya, India. Aertic Alpined Res 25:8-14.
Roberts MR (2002). Effects of forest plantation management on herbaceous-layer composition and diversity. Can J Bot 80:378-389.

Sala OE, Chapin FS, Armesto JJ, Berlow E, Bloomfield J, Dirzo R (2000). Global biodiversity scenarios for the year 2100 . Science 287:1770-1774.

Sanderson MA, Soder N, Brzezinski L, Muller L, Skinnners RH (2004). Plant species diversity influences forage production performance of dairy cattle on pasture. Grassland Sci Eur 9:632-634.

Shannon CE, Wiener W (1963). The Mathematical Theory of communication. University of lllinois press, Urbana, $117 \mathrm{p}$.

Simpson EH (1949). The Measurement of Diversity. Nature 163-688.

Singh YP, Kumar A, Rai JPN (2003). Species diversity as related to grazing pressure in alpine meadows of Nanda Devi Biosphere Reserve. Proceedings of National Seminar on Bioderversity Conservation and Management, (NSBCM' 03), Bhopal, 147-153 p.

Soil Survey Staff (1990). Soil Taxonomy: A Basic System for Classification, Mapping and Interpreting Soil Surveys. USDA Soil Conservation Services, Washington DC.

Thysell DR, Carey AB (2001). Manipulation of density of Pseudotsuga menziesii canopies: preliminary effects on understory vegetation. Can J For Res 31:1513-1525.

Vitousek P (1994). Beyond global warming: Ecology and global change. Ecol 75:1861-1876.

Wassel M (1969). Cocoa soils in Nigeria, 417-429 p. In: Proc of Second Internat Cocoa Research Conference, Brazil.

Wesenbeeck BKV, Mourik TV, Duivenvoorden JF, Cleef AM (2003). Strong effects of a plantation with Pinus patula on Andean subpáramo vegetation: a case study from Colombia. Biol Conserv 114:207-218.

Wienk CL, Sieg CH, McPherson GR (2004). Evaluating the role of cutting treatments, fire and soil seed banks in an experimental framework in ponderosa pine forests of the Black Hills, South Dakota. For Ecol Manage 192:375-393.

Wilson RC (1922). The Geology of the Western Railway Section 1. Bulletin No. 2. Geological Survey of Nigeria, Nigeria.

Yachi S, Loreau M (1999). Biodiversity and ecosystem productivity in a fluctuating environment: The insurance hypothesis. Proc Nat Acad Sci USA 96:1463-1468.

Yirdaw E (2001). Diversity of naturally-regenerated native woody species in forest plantations in the Ethiopian highlands. New For 22:159-177.

Yirdaw E, Luukkanen O (2003). Indigenous woody species diversity in Eucalyptus globulus Labill. ssp. globules plantations in the Ethiopian highlands. Biodiv Conserv 12:567-582.

Zenner EK, Kabrick JM, Jensen RG, Peck JE, Grabner JK (2006). Responses of ground flora to a gradient of harvest intensity in the Missouri Ozarks. For Ecol Manage 222:326334. 